\title{
Social Media Phenomena: Understanding the Perceived Features of Social Media and its effect on User Experiences and the Frequency of Usage
}

\begin{abstract}
This study explores the adoption of various kinds of social media application and their effect on user experiences. The study specifically investigates instant messaging applications (IMA) on the perceived features of IMA and user experiences. IMA are vital communication mediums that are tremendously used for communication throughout the Gulf countries. This study explores the phenomena of IMA trends and usage by examining user's contacts, experiences, and perceived features and its effect on use. A quantitative method was used for data collection that was based on random questionnaire distribution in public and private universities in Kuwait. Total sample size was 250 respondents. Results show differences in males and females in their perception about IMA, where females have greater IMA experiences and perceive more features than males when using IMA. Findings indicate the highest number of users (94.4\%) use WhatsApp, and second highest is (60.4\%) use Snap Chat. User's experience is found highest (87.6\%) in text chatting, and second highest (70.4\%) in photo sending. Results also show the highest number of contacts with whom they communicate is friends, and second highest with family. Results also show that the most key features of IMA perceived by users is their ability to interact with groups at the same time, and second highest feature is that it is free of charge.
\end{abstract}

Keywords: Social Media; Instant Messaging Applications (IMA); User Contacts; User Experiences; Perceived Features; Frequency of use; Duration of use 


\section{INTRODUCTION}

Instant Messaging (IM) compared to face-to-face informal communication is growing to a very high rate. It consists of huge base of users where communication is viable worldwide on a social or professional level. A very recent study in the same Gulf region as this study, specifically in Saudi Arabia examined the adoption of WhatsApp by teachers to communicate with students in educational setting. The study indicated that teachers using WhatsApp to communicate and transfer information to students felt more control and autonomy over the use of WhatsApp as their communication choice. The teachers felt empowered in a society where female actions are very hard and limited, teachers could transfer their skills, knowledge and overcome segregation issues using technology. WhatsApp was also used as a form of motivation for the students, where teachers would communicate with parents of their daughter's pictures when the students had outstanding performance (Alabbasi, 2016).

\section{Statement of the Problem}

The purpose of this study is to explore the social media phenomena in the country of Kuwait and to specifically investigate the perceived features of social media and their effect on how they enhance user's experiences which in turn lead to the frequency of usage.

Therefore, the aims of this study are to explore three important factors that encourage users to use IMA, they are users contact list, their experience with IMA, and IMA perceived features. No previous research has examined the relationship of the number and kinds of contacts users have on their phones in relation to their use, gender, age, and educational level. Scarce literature also exists for examining experiences of users with IMA and their perceived features of IMA that has led user to continue use. 


\section{Importance of the Study}

The importance of the study lies in three main points.

First, contribute to the scarce literature of IMA in Kuwait and specifically findings of the study can be generalized to the Gulf region, as all Gulf countries share similar cultural, economic, and financial environments.

Second, to explore three important constructs identified in literature as major predictors of use, they are user contacts, experiences, and perceived features of IMA and their effect on users within the population.

Third, to investigate the relationship of user contacts, experiences, and perceived features of IMA with gender, age, and education. And fourth, to examine the degree of importance of IMA as one of the main sources of communications technology in Kuwait.

\section{REVIEW OF LITERATURE}

Most previous research is focused on social use of IM (Grinter, \& Eldridge, 2001; Grinter \& Palen, 2002) while other IM research was examined in organizational contexts (Whittaker, Frohlich \& Daly-Jones, 1994). It has been evident that workplace IM conversations ranked highest for complex work discussions, and average for scheduling activities and coordination, and lowest for simple work interactions. Two main users were identified, heavy and light users. Heavy users used IM very frequently to work together in groups through discussing several topics through fast passed interactions. While light users used IM for infrequent slower paced interactions that 
involved routine multitasking activities (Isaacs, Walendowski, Whittaker, Schiano \& Kamm, 2002).

Isaacs, Walendowski, Whittaker, Schiano \& Kamm, (2002) highlighted three main dimensions that describe IM usage; they are the properties, functions, and patterns of using IM. In relation to IM properties, the first property has been evident that conversations of IM are brief and short focusing on rapid exchange of information, where discussions are like a collection of short questions and answers. The second property identified that users usually switch to other media such as phone calls when IM conversation gets too complex or long to discuss more detail when required. The third property was that users can multitask when IM, through frequently switching from one application to another when needed. Users are also able to carry on a conversation while undergoing other activities such as browsing the email, or searching a photo or a file (Isaacs, Walendowski, Whittaker, Schiano \& Kamm, 2002).

Second, in relation to IM functions Nardi, Whittaker \& Bradner (2000) studied 20 users in their workplace to investigate how they used IM functions. Their study identified four main functions frequently used by users. The first function is a quick question and clarification, it is the most commonly used and preferred method to communicate quickly and generate live responses on the spot from coworkers. The second function is coordination and scheduling work tasks, another favorite that is used frequently among teams to schedule work tasks and distribute work activities. The third function was coordination impromptu social meetings, and the fourth function was keeping in touch with family and friends both focus on social interactions between individuals and groups, sometimes regarded as social chatting and in some organizations, may be thought of as a waste of quality work time that lead to the loss of employee productivity. 
Third, is the pattern of use in relation to how frequent and with whom people use IM. Previous studies indicate on average users usually use IM through building a contact list through which communication ranges from 7 to 30 contacts (Grinter \& Palen, 2002; Mahowald \& Levitt, 2000; Rhinelander, 2000). Another study tested the frequency of use that resulted in two kinds of users, daily users and weekly users, where daily users reported more than 80\% (Radicati Group, 2001). While another study labeled two types of user's, the first is intense users, and they are users that are busy in sending many messages per day and the second is mainstream users, and they are users that send few messages per day (Rhinelander, 2000).

Previous studies tested the frequency of using WhatsApp among 270 college students in India using the period of use, which ranged in months; the number of friends ranging from 1 to more than 100; and the time of use during the day. Findings ranked from highest to lowest where students were found to use WhatsApp the highest for international chatting, group chatting, voice chatting, sending images, sending videos, and the lowest is normal local chatting (Maheswari, 2014).

Other studies tested the frequency of using IM among teenage students aged 19 and below in the United States and United Kingdom. Study shows that a buddy-list or friends contact list is identified as a core prerequisite to IM usage. Findings indicate that teenager's engagement of IM ranged in three main categories, first, socializing with friends and colleagues in informal communication, second, event planning, such as studying together, watching movies, dinner, gathering, and coordinating activities etc.; and third, school work collaboration where they would discuss homework exam notes and share feedback, ask each other questions about school work. All students reported multitasking where they would frequently engage in more than one conversation at the same time (Grinter \& Palen, 2002). 
A similar study was performed among 131 participants in Spain ranging from age 20-60 males and females to test the difference in using the traditional SMS with WhatsApp. Findings indicate the frequency of using WhatsApp was a lot higher than SMS and more important factor identified that drove usage was the cost factor. The second factor was the social factor of WhatsApp. WhatsApp was used more frequently for several purposed as the main means of communication (Church \& de Oliveira, 2013).

As evident from previous literature that most studies are focused on European and international regions. For that reason, the purpose of this study is to explore the growing use IMA in Kuwait, as research is scarce and limited in the field of technology adoption. This study aims to test the relationship of three important supporting variables: first, user's contact kinds (friends, family, work colleagues, and businesses) when using IMA. Previous research has proven users contacts lists or buddy lists are important predictors of IMA use (Grinter \& Palen, 2002). Second, kind of IMA experience (text chat, voice chat, group chat, voice call, video call, photo sending, video sending, location sending) when using IMA. Previous studies ranging varying Western countries have examined users contacts lists and past experiences and its effect on using IMA. However, to date no studies throughout the Gulf countries have examined the effect of users contact kinds, user experiences, and the most important features that are perceived by users and that drive user acceptance of IMA.

Therefore, this paper aims at filling the gap in literature by examining the relationship of user's contacts, experiences, and perceived features of using IMA with age, gender, and education level and its effect on using IMA. Studies have previously stated that intense or heavy users of IMA are important segments to study as they are the driving force behind the IMA communication (Rhinelander, 2000). Third, user's perceptions about important features when using IMA. Previous 
studies have emphasized important features that are considered important predictors of adoption and use of IMA (Nardi, Whittaker \& Bradner, 2000). Therefore, the previously mentioned three variables will be tested with three demographic factors: gender, age, and education.

\section{Research Hypothesis}

First, in relation to gender, the following hypotheses are examined:

H1: There is no significant difference in the opinion of male and female students about their perception of contact kinds when using IMA.

H2: There is no significant difference in the opinion of male and female students about their perception of application experiences when using IMA.

H3: There is no significant difference in the opinion of male and female students about their perception of application features when using IMA.

Second, in relation to age, the following hypotheses are examined:

H4: There is no significant difference in the opinion of students from different age levels about their perception of contact kinds when using IMA.

H5: There is no significant difference in the opinion of students from different age levels about their perception of application experiences when using IMA.

H6: There is no significant difference in the opinion of students from different age levels about their perception of application features when using IMA.

Third, in relation to education, the following hypothesis is examined: 
H7: There is no significant difference in the opinion of students from different college levels about contact kinds, kinds of application experiences, and perceived application features when using IMA.

Fourth, the greater the use of the mobile the more frequent and the longer users are going to use mobile social media. To explore the frequency and duration of mobile social media usage the following research questions are examined:

Q1: What is the relationship between user's gender, age, and education to the frequency of using mobile social media?

Q2: What is the relationship between user's gender, age, and education to the length of using mobile social media?

Therefore, this paper aims at filling the gap in literature by examining the relationship of user's contacts kinds, kinds of experiences when using IMA, and the most important features of IMA that are driving its use in relation to user's frequency and duration of use.

In terms of contact kinds, the study aims at understanding the most accessed category of contacts that users communicate with using IMA, where four important categories of contacts are examined, they are friends, family, work colleagues, and business and their effect on IMA use in terms of gender, age, and education.

In relation to kinds of experiences with IMA, the study aims at exploring the highest user experiences of using IMA, where eight important categories of the technology are accessed by users, they are text chat, photo sending, group chat, voice call, video sending, voice chat, location sending, and video call and their effect on IMA use in terms of gender, age, and education. 
In terms of perceived features of using IMA, the study aims at examining the most important features of using IMA, where eight important categories are examined, they are the ability to interact with groups, free of charge, simplicity, personal, shows when the other person is reply, shows the delivery of the message, shows when the message is read, amount of people that use IMA and their effect on IMA use in terms of gender, age, and education.

\section{METHDOLOGY}

This study investigates user's intention and frequency to use mobile instant messaging applications. The basic objective of the research was to explore the various kinds of instant messaging applications people are using and the frequency of use. The various functions and features of IMA have been investigated. IMA allow users to exchange messages without having to pay, they free of charge mobile communication services that people use through accessing the Internet.

\section{Pilot Study}

A preliminary pilot study was performed with some university students to understand their point of view about social media usage in terms of important and frequency of usage. Accordingly, the questionnaire was designed.

\section{Sample Design}

To test user's frequency of using IMA a questionnaire was designed and randomly distributed to participants studying in public and private university campuses. It included various kinds of IMA communication functions that were mentioned by students in the exploratory study, such as 
text/voice/group chat; voice/video call; photo/video/location sending. The validity and reliability of the questionnaire was measured. To measure the validity of the questionnaire, it was circulated to 5 professors at Kuwait University to get their feedback. Based on their suggestions and recommendations, the questionnaire was modified. The questionnaire was circulated to about 270 participants, after which 20 had missing information and were removed from the final sample that totaled 250. Thirteen dependent variables were measured using the five level 'Likert Scales', where 1 represents 'never', 2 represents 'rarely', 3 represents 'sometimes' 4 represents 'most of the times' and 5 represents 'always' and eight dependent variables were measured using the other five level 'Likert Scales', where 1 represents 'strongly disagree', 2 represents 'disagree', 3 represents 'undecided' 4 represents 'agree' and 5 represents 'strongly agree'.

\section{Data Analysis}

Reliability of the questionnaire was measured by using Cronbach's Alpha of SPSS-20 software program. The Reliability of all the twenty dependent variables was measured and it was 0.889 which shows a very strong reliability. The hypotheses were tested to show the percentage values, mean values, standard deviation and t-test.

The final research data sample consists of 250 participants. The male participants were 100 (40\%) and female participants were $150(60 \%)$. In terms of age, $171(68.4 \%)$ participants were in the age group of 'up to 29 years' and $79(31.6 \%)$ participants were in the age group of '30 years and above'. Concerning the level of education of 87 (34.8\%) participants was 'up to Diploma' and 163 $(65.2 \%)$ were 'bachelor and above'. 


\section{FINDINGS AND DISCUSSION}

The research resulted in interesting findings it was observed that all the $100 \%$ participants have shown that they are already using IMA. This finding indicates that $100 \%$ of the population are using instant messaging applications and are knowledgeable about it.

In terms of participants' experience of using 'Instant messaging Applications' participants have experienced 'text chat" the highest; the second highest in IMA user experience is 'photo sending'; and the third highest is 'group chat'. The lowest number of 'instant messaging applications experience' that the participants use is 'video call'.

Concerning the number of contacts, 119 (47.6\%) participants have number of contacts that use 'Instant messaging Applications' as 'less than 60 contacts' and 132 (52.4\%) participants have number of contacts that use 'Instant messaging Applications' as '60 contacts and more'.

Concerning the most important features of IMA among users, the highest most important feature of instant messaging applications that the participants use is, 'Its ability to interact with groups at the same time'. The second most important feature of instant messaging applications that the participants use is, 'It is free of charge'. The third most important features of instant messaging applications that the participants use is, 'It is simple'. The lowest most important features of instant messaging applications that the participants use is, 'The amount of people that use is its contacts'.

The following table (1) shows the main kinds of 'Instant Messaging Applications' used by participants. It is a multiple question i.e. participants can choose more than one applications. The 
table (1) shows the results of the number of participants and their percentage of using these applications in the descending order.

The table (1) shows that the highest number of participants 236 (94.4\%) use WhatsApp. The second highest number of participants $151(60.4 \%)$ use Snap Chat and third highest number of participants 76 (30.4\%) use Viber. The lowest number of participants 23 (9.2\%) use Line.

Table (1)

The Main kinds of 'Instant Messaging Application' use. The Table is sorted in the Descending Order as per their use

\begin{tabular}{|l|c|}
\hline Variables & The number of participants and their use of IMA \\
\hline WhatsApp & $236(94.4 \%)$ \\
\hline Snap Chat & $151(60.4)$ \\
\hline Viber & $76(30.4 \%)$ \\
\hline Facebook Messenger & $52(20.8 \%)$ \\
\hline Skype & $52(20.8 \%)$ \\
\hline Kik & $36(14.4 \%)$ \\
\hline Tango & $28(11.2 \%)$ \\
\hline Line & $23(9.2 \%)$ \\
\hline
\end{tabular}

The following table (2) shows the frequency of participants experience in using 'Instant Messaging Applications'. It is a multiple question i.e. participants can choose more than one applications. The 
table (2) shows the results of the number of participants and their percentage showing their experience in using Instant Message Application in the descending order.

The table (2) shows that the highest number of participants $219(87.6 \%)$ experience in using 'Instant messaging Applications' is in text Chat. The second highest number of participants 176 (70.4\%) experience in using 'Instant messaging Applications' is in Photo Sending and the third highest number of participants 169 (67.6\%) experience in using 'Instant messaging Applications' is in Group Chat. The lowest number of participants 107 (42.8\%) experience in using 'Instant messaging Applications' is in Video Call.

Table (2)

Participants Experience in using 'Instant Messaging Applications'

The Table is sorted in the Descending Order as per their use

\begin{tabular}{|l|c|}
\hline Variables & $\begin{array}{r}\text { The number of participants and their percentage showing their } \\
\text { experience in using Instant Message Application }\end{array}$ \\
\hline Text chat & $219(87.6 \%)$ \\
\hline Photo sending & $176(70.4 \%)$ \\
\hline Group chat & $169(67.6 \%)$ \\
\hline Voice call & $167(66.8 \%)$ \\
\hline Video sending & $159(63.6 \%)$ \\
\hline Voice chat & $157(62.8 \%)$ \\
\hline Location sending & $138(55.2 \%)$ \\
\hline
\end{tabular}




\begin{tabular}{|l|c|}
\hline Video call & $107(42.8 \%)$ \\
\hline
\end{tabular}

The following table (3) shows the number of contacts that the respondents communicate with using the instant messaging applications. Table (3) also shows the number of contacts, percentages along with their mean values, that they communicate with, in various degrees (never, rarely, sometimes, most of the times \& always), in using Instant Message Applications, in the descending order.

The table (3) shows that the highest number of contacts with whom the participants communicate is "friends" (Mean $=4.2$ ), and the lowest number of contacts with whom the participants communicate is "Businesses / shops" (Mean = 2.56).

Table (3)

Contacts (kinds) that Users communicate with using instant messaging applications The column values show the count and their percentages

\begin{tabular}{|c|c|c|c|c|c|c|}
\hline $\begin{array}{l}\text { Contacts (kinds) that } \\
\text { users communicate with } \\
\text { using instant messaging } \\
\text { applications }\end{array}$ & $\begin{array}{l}\text { Never } \\
\text { (1) }\end{array}$ & $\begin{array}{l}\text { Rarely } \\
\text { (2) }\end{array}$ & $\begin{array}{l}\text { Sometimes } \\
\text { (3) }\end{array}$ & $\begin{array}{l}\text { Most of } \\
\text { the time } \\
\text { (4) }\end{array}$ & $\begin{array}{c}\text { Always } \\
\text { (5) }\end{array}$ & Mean \\
\hline Friends & $\begin{array}{c}5 \\
2.0 \%\end{array}$ & $\begin{array}{c}7 \\
2.8 \%\end{array}$ & $\begin{array}{c}34 \\
13.6 \%\end{array}$ & $\begin{array}{c}90 \\
36.0 \%\end{array}$ & $\begin{array}{c}114 \\
45.6 \%\end{array}$ & 4.20 \\
\hline Family & $\begin{array}{c}5 \\
2.0 \%\end{array}$ & $\begin{array}{c}9 \\
3.6 \%\end{array}$ & $\begin{array}{c}49 \\
19.6 \%\end{array}$ & $\begin{array}{c}80 \\
32.0 \%\end{array}$ & $\begin{array}{c}107 \\
42.8 \%\end{array}$ & 4.10 \\
\hline Work Colleagues & $\begin{array}{c}15 \\
6.0 \%\end{array}$ & $\begin{array}{c}52 \\
20.8 \%\end{array}$ & $\begin{array}{c}92 \\
36.8 \%\end{array}$ & $\begin{array}{c}54 \\
21.6 \%\end{array}$ & $\begin{array}{c}37 \\
14.8 \%\end{array}$ & 3.18 \\
\hline Businesses / shops & $\begin{array}{c}47 \\
18.8 \%\end{array}$ & $\begin{array}{c}81 \\
32.4 \%\end{array}$ & $\begin{array}{c}78 \\
31.2 \%\end{array}$ & $\begin{array}{c}22 \\
8.8 \%\end{array}$ & $\begin{array}{c}22 \\
8.8 \%\end{array}$ & 2.56 \\
\hline
\end{tabular}


The following table (4) shows the experience of participants in using various 'instant messaging applications' that they use in communication. Table (4) also shows the number, percentages along with their mean values, that they communicate with, in various degrees (never, rarely, sometimes, most of the times \& always), in using Instant Message Applications, in the descending order. The table (4) shows that the highest number of 'instant messaging applications experience' that the participants use is "text chat" (Mean $=4.34)$, the second highest number of 'instant messaging applications experience' that the participants use is 'photo sending' (Mean $=3.81$ ), and the third highest number of 'instant messaging applications experience' that the participants use is 'group chat' (Mean $=3.79)$. The lowest number of 'instant messaging applications experience' that the participants use is 'video call' (Mean $=2.84)$.

Table (4)

The Instant Messaging Application Experience

The column values show the count and their percentage

\begin{tabular}{|l|c|c|c|c|c|c|}
\hline $\begin{array}{l}\text { Instant Messaging } \\
\text { Applications } \\
\begin{array}{l}\text { Experience } \\
\text { includes }\end{array}\end{array}$ & $\begin{array}{c}\text { Never } \\
(1)\end{array}$ & $\begin{array}{c}\text { Rarely } \\
(2)\end{array}$ & $\begin{array}{c}\text { Sometimes } \\
(3)\end{array}$ & $\begin{array}{c}\text { Most of } \\
\text { the time } \\
(4)\end{array}$ & $\begin{array}{c}\text { Always } \\
(5)\end{array}$ & Mean \\
\hline Text chat & 5 & 7 & 32 & 59 & 147 & 4.34 \\
\hline Photo sending & $2.0 \%$ & $2.8 \%$ & $12.8 \%$ & $23.6 \%$ & $58.8 \%$ & $\begin{array}{c}78 \\
\text { Group chat }\end{array}$ \\
\hline $4.4 \%$ & $6.4 \%$ & $24.4 \%$ & $33.6 \%$ & $31.2 \%$ & 3.81 \\
\hline Voice call & $3.2 \%$ & $9.2 \%$ & $26.4 \%$ & $28.0 \%$ & $33.2 \%$ & 3.79 \\
\hline Voice chat & 12 & 28 & 77 & 55 & 78 & 3.64 \\
\hline
\end{tabular}




\begin{tabular}{|l|c|c|c|c|c|c|}
\hline & $6.4 \%$ & $8.8 \%$ & $32.8 \%$ & $24.8 \%$ & $27.2 \%$ & \\
\hline \multirow{2}{*}{ Video sending } & 13 & 38 & 70 & 58 & 71 & \multirow{2}{*}{3.54} \\
\hline \multirow{2}{*}{ Location sending } & $5.2 \%$ & $15.2 \%$ & $28.0 \%$ & $23.2 \%$ & $28.4 \%$ & \\
\hline \multirow{2}{*}{ Video call } & $35.0 \%$ & 50 & 84 & 51 & 30 & \multirow{2}{*}{2.96} \\
& 35 & $82.0 \%$ & $33.6 \%$ & $20.4 \%$ & $12.0 \%$ & \\
\hline
\end{tabular}

The following table (5) shows the most important features of instant messaging applications. The table (5) shows the number, percentages along with their mean values of 'the most important features of instant messaging applications' that the participants use it, in various degrees (never, rarely, sometimes, most of the times \& always), in the descending order. The table (5) shows that the highest number of 'the most important features of instant messaging applications' that the participants use is, 'Its ability to interact with groups at the same time', $($ Mean $=4.14)$. The second highest number of 'the most important features of instant messaging applications', that the participants use is, 'It is free of charge', (Mean $=4.09$ ), The third highest number 'the most important features of instant messaging applications', that the participants use is, 'It is simple', $($ Mean $=4.08)$. The lowest number of 'the most important features of instant messaging applications', that the participants use is, 'The amount of people that use is its contacts', (Mean = 3.70).

Table (5)

The Most Important Perceived Features of Instant Messaging Applications

The column values show the count and their percentage 


\begin{tabular}{|c|c|c|c|c|c|c|}
\hline $\begin{array}{l}\text { Important Perceived features } \\
\text { of instant messaging } \\
\text { applications are: }\end{array}$ & $\begin{array}{l}\text { Never } \\
(1)\end{array}$ & $\begin{array}{l}\text { Rarely } \\
\text { (2) }\end{array}$ & $\begin{array}{l}\text { Sometimes } \\
\text { (3) }\end{array}$ & $\begin{array}{l}\text { Most of } \\
\text { the time } \\
\text { (4) }\end{array}$ & $\begin{array}{l}\text { Always } \\
\text { (5) }\end{array}$ & Mean \\
\hline $\begin{array}{l}\text { Ability to interact with } \\
\text { groups at the same time }\end{array}$ & $\begin{array}{c}4 \\
1.6 \%\end{array}$ & $\begin{array}{c}14 \\
5.6 \%\end{array}$ & $\begin{array}{c}31 \\
12.4 \%\end{array}$ & $\begin{array}{c}96 \\
38.4 \%\end{array}$ & $\begin{array}{c}105 \\
42.0 \%\end{array}$ & 4.14 \\
\hline It is free of charge & $\begin{array}{c}4 \\
1.6 \%\end{array}$ & $\begin{array}{c}11 \\
4.4 \%\end{array}$ & $\begin{array}{c}40 \\
16.0 \%\end{array}$ & $\begin{array}{c}98 \\
39.2 \%\end{array}$ & $\begin{array}{c}97 \\
38.8 \%\end{array}$ & 4.09 \\
\hline It is simple & $\begin{array}{c}5 \\
2.0 \%\end{array}$ & $\begin{array}{c}6 \\
2.4 \%\end{array}$ & $\begin{array}{c}39 \\
15.6 \%\end{array}$ & $\begin{array}{c}113 \\
45.2 \%\end{array}$ & $\begin{array}{c}87 \\
34.8 \%\end{array}$ & 4.08 \\
\hline It is personal & $\begin{array}{c}5 \\
2.0 \%\end{array}$ & $\begin{array}{c}22 \\
8.8 \%\end{array}$ & $\begin{array}{c}28 \\
11.2 \%\end{array}$ & $\begin{array}{c}111 \\
44.4 \%\end{array}$ & $\begin{array}{c}84 \\
33.6 \%\end{array}$ & 3.99 \\
\hline $\begin{array}{l}\text { It shows when the other } \\
\text { person is typing a reply }\end{array}$ & $\begin{array}{c}7 \\
2.8 \%\end{array}$ & $\begin{array}{c}26 \\
10.4 \%\end{array}$ & $\begin{array}{c}41 \\
16.4 \%\end{array}$ & $\begin{array}{c}91 \\
36.4 \%\end{array}$ & $\begin{array}{c}85 \\
34.0 \%\end{array}$ & 3.88 \\
\hline $\begin{array}{l}\text { It shows when the message } \\
\text { is delivered }\end{array}$ & $\begin{array}{c}4 \\
1.6 \%\end{array}$ & $\begin{array}{c}25 \\
10.0 \%\end{array}$ & $\begin{array}{c}47 \\
18.8 \%\end{array}$ & $\begin{array}{c}113 \\
45.2 \%\end{array}$ & $\begin{array}{c}61 \\
24.4 \%\end{array}$ & 3.81 \\
\hline $\begin{array}{l}\text { it shows when the message } \\
\text { is read }\end{array}$ & $\begin{array}{c}9 \\
3.6 \%\end{array}$ & $\begin{array}{c}24 \\
9.6 \%\end{array}$ & $\begin{array}{c}45 \\
18.0 \%\end{array}$ & $\begin{array}{c}104 \\
41.6 \%\end{array}$ & $\begin{array}{c}68 \\
27.2 \%\end{array}$ & 3.79 \\
\hline $\begin{array}{l}\text { The amount of people that } \\
\text { use it- contacts }\end{array}$ & $\begin{array}{c}21 \\
8.4 \%\end{array}$ & $\begin{array}{c}18 \\
7.2 \%\end{array}$ & $\begin{array}{c}32 \\
12.8 \%\end{array}$ & $\begin{array}{c}122 \\
48.8 \%\end{array}$ & $\begin{array}{c}57 \\
22.8 \%\end{array}$ & 3.70 \\
\hline
\end{tabular}

\section{T-Test with respect to Gender on Contact Kinds; Application Experience; and Perceived Features of IMA:}

T-test is applied with respect to gender on various newly created variables as shown in the following table (6). The important results from the table (6) show that significant difference exists between male participants and female participants for two (application experience and perceived features when using IMA) out of the three dependent variables at $95 \%$ confidence interval. 
Table (6) shows that there is no significant difference at (0.5) with respect to gender (male, female) on 'Overall user perception about various contacts (kinds) that they communicate with using instant messaging applications', in relation to user's perception about the kinds of contacts they communicate with when using IMA. Therefore, H1: There is no significant difference in the opinion of male and female students about their perception of contact kinds when using IMA has been proven true. This means that there's no difference in relation to the kinds of contacts males and females use to communicate with using IMA.

Table (6) shows that there is a statistical significant difference at (.05) with respect to gender (male, female) on 'Overall user perception about various instant messaging application experiences', $t$ $(248)=-4.09, \mathrm{p}<.001$. The mean values show that female participants as an average feel significantly more 'Overall user perception about various instant messaging application experiences' $(M=3.72, S D=0.74)$ than the male participants feel about it $(M=3.33, S D=0.73)$. Therefore, H2: There is no significant difference in the opinion of male and female students about their perception of application experiences when using IMA has been proven false. This means that female users are more aware of the advantages and the features of IMA than male users. Probably a good explanation for this finding is the fact that females are probably more social, which is a characteristic of Middle Eastern cultures, which in turn may lead to increased use and experiences in IMA.

Table (6) shows that there is a statistical significant difference at (.05) with respect to gender (male, female) on 'Overall user perception about important application features of instant messaging applications', $\mathrm{t}(248)=-3.52, \mathrm{p}<.001$. The mean values show that female participants as an 
average feel significantly more 'Overall user perception about important application features of instant messaging applications' $(\mathrm{M}=4.06, \mathrm{SD}=0.64)$ than the male participants feel about it $(\mathrm{M}=3.74, \mathrm{SD}=0.80)$. Therefore, $\mathrm{H} 3$ : There is no significant difference in the opinion of male and female students about their perception of application features when using IMA has been proven false. This finding can also be explained in relation to the previous finding that females perceive greater experiences, then it makes sense that females also perceive and are aware of more features when using IMA than males do.

Table: (6)

T-Test with respect to "Gender" on Contact Kinds; Application Experience; and Perceived Features of IMA

\begin{tabular}{|c|c|c|c|c|c|c|c|}
\hline Variables & Gender & $\mathrm{N}$ & Mean & $\begin{array}{c}\text { Std. } \\
\text { Deviation }\end{array}$ & $\mathrm{t}$ & df & $\begin{array}{c}\text { Sig. } \\
\text { (2-tailed) }\end{array}$ \\
\hline \multirow{2}{*}{$\begin{array}{l}\text { Overall user perception about } \\
\text { various contacts (kinds) that } \\
\text { they communicate with using } \\
\text { instant messaging } \\
\text { applications }\end{array}$} & Male & 100 & 3.46 & 0.78 & \multirow{2}{*}{-1.06} & \multirow[b]{2}{*}{248} & \multirow[b]{2}{*}{.291} \\
\hline & Female & 150 & 3.55 & 0.65 & & & \\
\hline \multirow{2}{*}{$\begin{array}{l}\text { Overall user perception about } \\
\text { various instant messaging } \\
\text { application experiences }\end{array}$} & Male & 100 & 3.33 & 0.73 & \multirow{2}{*}{-4.09} & \multirow{2}{*}{248} & \multirow{2}{*}{.000} \\
\hline & Female & 150 & 3.72 & 0.74 & & & \\
\hline \multirow{2}{*}{$\begin{array}{l}\text { Overall user perception about } \\
\text { important features of instant } \\
\text { messaging applications }\end{array}$} & Male & 100 & 3.74 & 0.80 & \multirow{2}{*}{-3.52} & \multirow{2}{*}{248} & \multirow{2}{*}{.001} \\
\hline & Female & 150 & 4.06 & 0.64 & & & \\
\hline
\end{tabular}

\section{T-Test with respect to Age on Contact Kinds; Application Experience; and Perceived}

\section{Features of IMA:}


T-test is applied with respect to age on various newly created variables as shown in the following table (7). The important results from the table (7) show that significant difference exists between the participants who are in the age group of 'up to 29 ' and the participants who are in the age group of '30 and more' for one (application experience) out of the three dependent variables at 95\% confidence interval.

Table (7) shows that there is no statistical difference at (.05) with respect to age ((up to 29), (30 and more)) on 'Overall user perception about various contacts (kinds) that they communicate with using instant messaging applications'. Therefore, H4: There is no significant difference in the opinion of students from different age levels about their perception of contact kinds when using IMA has been proved true.

Table (7) shows that there is a statistical significant difference at (.05) with respect to age ((up to 29), (30 and more)) on 'Overall user perception about various instant messaging application experiences', $\mathrm{t}(191.46)=3.01, \mathrm{p}<.01$. The mean values show that participants who are in the age group of 'up to 29' as an average feel significantly more on 'Overall user perception about various instant messaging application experiences' $(\mathrm{M}=3.65, \mathrm{SD}=0.80)$ than the participants who are in the age group of ' 30 and more' feel about it $(\mathrm{M}=3.37, \mathrm{SD}=0.62)$. Therefore, $\mathrm{H} 5$ : There is no significant difference in the opinion of students from different age levels about their perception of application experiences when using IMA has been proven false.

Table (7) shows that there is no statistical difference at (.05) with respect to age ((up to 29), (30 and more)) on 'Overall user perception about important features of instant messaging applications'. Therefore, H6: There is no significant difference in the opinion of students from 
different age levels about their perception of application features when using IMA has been proven true.

Table: (7)

T-Test with respect to "Age" on Contact Kinds; Application Experience; and Perceived Features of IMA

\begin{tabular}{|c|c|c|c|c|c|c|c|}
\hline Variables & Age & $\mathrm{N}$ & Mean & $\begin{array}{c}\text { Std. } \\
\text { Deviation }\end{array}$ & $\mathrm{t}$ & df & $\begin{array}{c}\text { Sig. } \\
\text { (2-tailed) }\end{array}$ \\
\hline \multirow{2}{*}{$\begin{array}{l}\text { Overall user perception } \\
\text { about various contacts } \\
\text { (kinds) that they } \\
\text { communicate with using } \\
\text { instant messaging } \\
\text { applications }\end{array}$} & Up to 29 & 171 & 3.49 & 0.73 & \multirow[b]{2}{*}{-0.67} & \multirow[b]{2}{*}{248.00} & \multirow[b]{2}{*}{0.51} \\
\hline & 30 and More & 79 & 3.56 & 0.67 & & & \\
\hline \multirow{2}{*}{$\begin{array}{l}\text { Overall user perception } \\
\text { about various instant } \\
\text { messaging application } \\
\text { experiences }\end{array}$} & Up to 29 & 171 & 3.65 & 0.80 & \multirow{2}{*}{3.01} & \multirow{2}{*}{191.46} & \multirow{2}{*}{0.00} \\
\hline & 30 and More & 79 & 3.37 & 0.62 & & & \\
\hline \multirow{2}{*}{$\begin{array}{l}\text { Overall user perception } \\
\text { about important features } \\
\text { of instant messaging } \\
\text { applications }\end{array}$} & Up to 29 & 171 & 3.96 & 0.74 & \multirow[b]{2}{*}{0.67} & \multirow[b]{2}{*}{248.00} & \multirow[b]{2}{*}{0.50} \\
\hline & 30 and More & 79 & 3.89 & 0.68 & & & \\
\hline
\end{tabular}

\section{T-Test with respect to Education on Contact Kinds; Application Experience; and Perceived}

\section{Features of IMA:}

T-test is applied with respect to education on various newly created variables as shown in the following table (8). The results from the table (8) show that no significant difference exists between the participants with respect to their education ((up to diploma), (Bachelor and more)). User's education level does not have any effect on the 'Overall user perception about various contacts (kinds) that they communicate with using instant messaging applications'; 'Overall user perception 
about various instant messaging application experiences'; 'Overall user perception about important features of instant messaging applications'. Therefore, H7: There is no significant difference in the opinion of students from different college levels about contact kinds, kinds of application experiences, and perceived application features when using IMA has been proved true. This finding explains that the level of education does not influence IMA use and this finding can be justified by observing and understanding that all categories of users have adopted some sort of IMA regardless of kind, whether they are kids, teenagers, young adults, or older adults, regardless of the level of education all users can use and take advantage of the technology. Therefore, from this perspective education will not have a significant effect on user's kinds of contacts, or application experience, or their perceived features when using IMA. This can also be explained from the IMA technology perspective that it is an easy technology that can be accessed by all.

Table: (8)

\section{T-Test with respect to "Education" on Contact Kinds; Application Experience; and}

Perceived Features of IMA

\begin{tabular}{|c|c|c|c|c|c|c|c|}
\hline Variables & Education & $\mathrm{N}$ & Mean & $\begin{array}{c}\text { Std. } \\
\text { Deviation }\end{array}$ & $\mathrm{t}$ & $\mathrm{df}$ & $\begin{array}{c}\text { Sig. } \\
\text { (2-tailed) }\end{array}$ \\
\hline \multirow{2}{*}{$\begin{array}{l}\text { Overall user perception } \\
\text { about various contacts } \\
\text { (kinds) that they } \\
\text { communicate with using } \\
\text { instant messaging } \\
\text { applications }\end{array}$} & $\begin{array}{l}\text { Up to } \\
\text { Diploma }\end{array}$ & 87 & 3.51 & 0.68 & \multirow[b]{2}{*}{-0.07} & \multirow[b]{2}{*}{248.00} & \multirow[b]{2}{*}{0.94} \\
\hline & $\begin{array}{l}\text { Bachelor and } \\
\text { more }\end{array}$ & 163 & 3.52 & 0.72 & & & \\
\hline \multirow{2}{*}{$\begin{array}{l}\text { Overall user perception } \\
\text { about various instant } \\
\text { messaging application } \\
\text { experiences }\end{array}$} & $\begin{array}{l}\text { Up to } \\
\text { Diploma }\end{array}$ & 87 & 3.61 & 0.70 & \multirow{2}{*}{0.80} & \multirow{2}{*}{248.00} & \multirow{2}{*}{0.42} \\
\hline & $\begin{array}{l}\text { Bachelor and } \\
\text { more }\end{array}$ & 163 & 3.53 & 0.79 & & & \\
\hline \multirow{2}{*}{$\begin{array}{l}\text { Overall about the most } \\
\text { Important features of } \\
\text { instant messaging } \\
\text { applications that they } \\
\text { feel }\end{array}$} & $\begin{array}{l}\text { Up to } \\
\text { Diploma }\end{array}$ & 87 & 4.06 & 0.62 & \multirow{2}{*}{1.93} & \multirow{2}{*}{248} & \multirow{2}{*}{0.06} \\
\hline & $\begin{array}{l}\text { Bachelor and } \\
\text { more }\end{array}$ & 163 & 3.87 & 0.76 & & & \\
\hline
\end{tabular}


The Table (9) shows the frequency of using instant messaging applications. The highest number of participants $123(49.2 \%)$ use instant messaging applications more than 10 times a day. The lowest number of participants 14 (5.6\%) use instant messaging applications about 1-2 times in a month.

Table: (9)

Frequency of using Instant Messaging Applications

\begin{tabular}{|l|c|c|}
\hline \multicolumn{1}{|c|}{ Frequency } & Number of Participants & $\%$ \\
\hline Between 1-2 times a month & 14 & 5.6 \\
\hline Between 1-2 times a week & 15 & 6.0 \\
\hline Between 1-2 times a day & 28 & 11.2 \\
\hline Between 3-5 times a day & 40 & 16.0 \\
\hline Between 6-9 times a day & 30 & 49.0 \\
\hline More than 10 times a day & 123 & 49.2 \\
\hline
\end{tabular}

\section{Chi-square test between gender and 'Duration of using instant message applications'}

A chi-square test of independence was performed to examine the relation between gender and 'length of using instant message applications'. The relation between these two variables was not significant, $\mathrm{X} 2(1, \mathrm{~N}=250)=0.000, \mathrm{p}>.05(\mathrm{p}=1.00)$. 
The following table (10) shows all the important results of Pearson Chi-square test. The table also shows the frequency distribution of the variables in the different cells along with the value of chi-square, df and 'Asymptotic Significance (2-sided)'.

Table: (10)

Chi-Square Test between Gender and 'Duration of Using Instant Messaging Application'

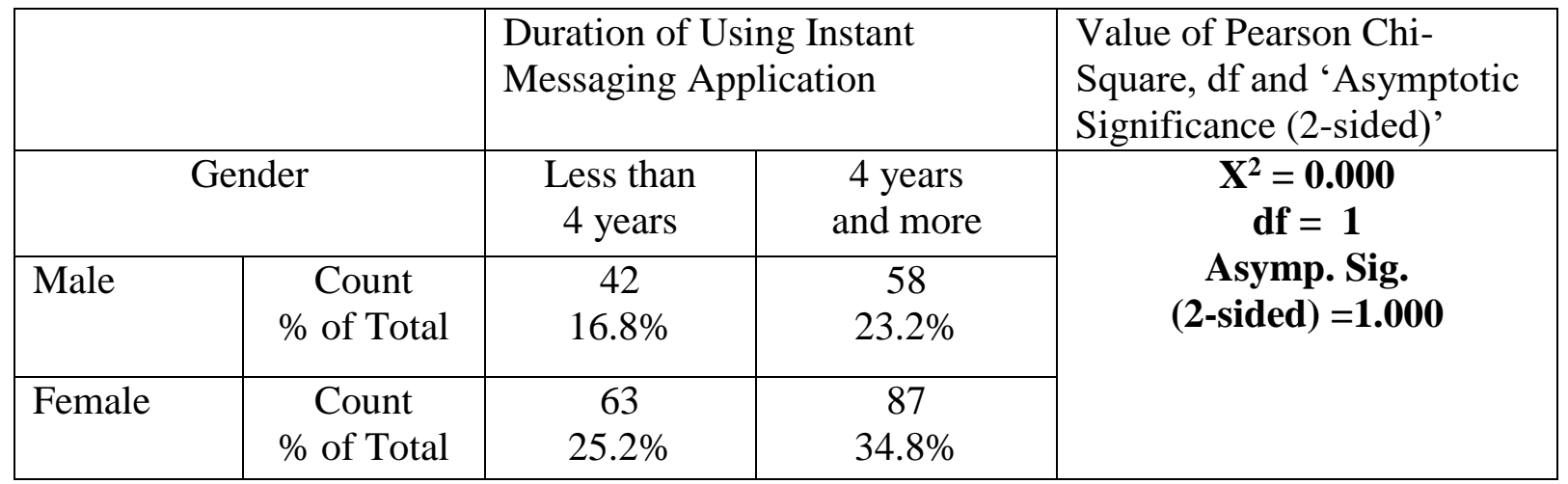

\section{Chi-square test between gender and 'frequency of using instant message applications'}

A chi-square test of independence was performed to examine the relation between gender and 'frequency of using instant message applications'. The relation between these two variables was not significant, $\mathrm{X} 2(1, \mathrm{~N}=250)=0.323, \mathrm{p}>.05(\mathrm{p}=0.57)$.

The following table (11) shows all the important results of Pearson Chi-square test. The table also shows the frequency distribution of the variables in the different cells along with the value of chi-square, df and 'Asymptotic Significance (2-sided)'.

Table: (11)

Chi-Square Test between Gender and 'Frequency of Using Instant Messaging Application' 


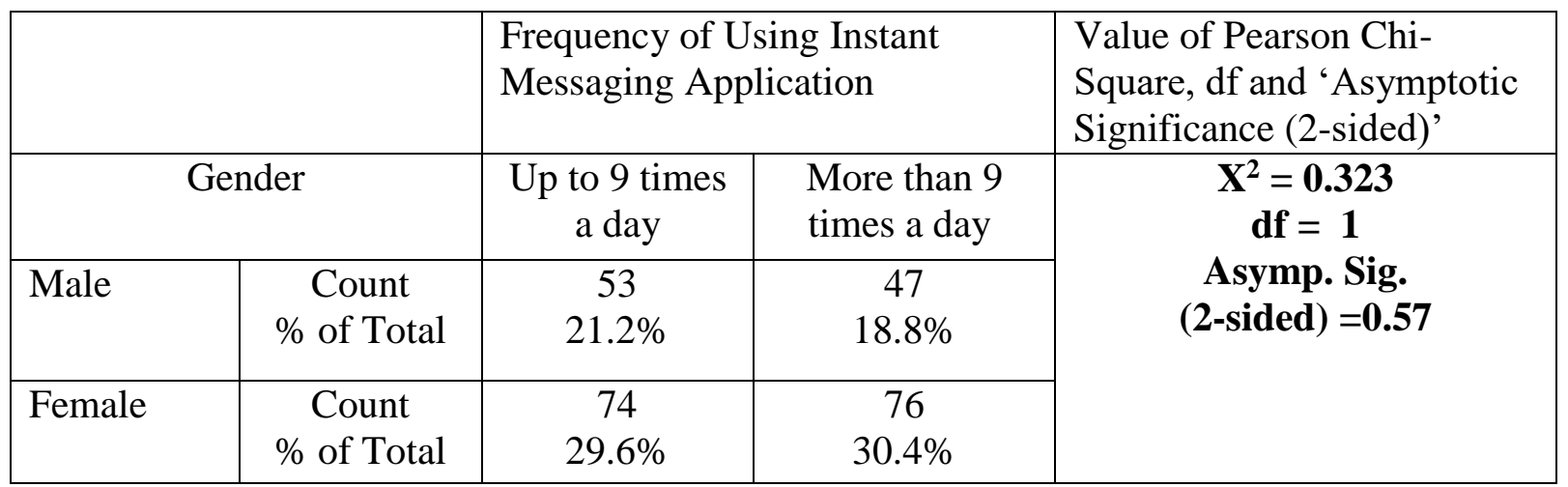

\section{Chi-square test between age and 'Duration of using instant message applications'}

A chi-square test of independence was performed to examine the relation between age and 'duration of using instant message applications'. The relation between these two variables was not significant, $\mathrm{X} 2(1, \mathrm{~N}=250)=1.327, \mathrm{p}>.05(\mathrm{p}=0.249)$.

The following table (12) shows all the important results of Pearson Chi-square test. The table also shows the frequency distribution of the variables in the different cells along with the value of chi-square, df and 'Asymptotic Significance (2-sided)'.

Table: (12)

Chi-Square Test between Age and 'Duration of Using Instant Messaging Application'

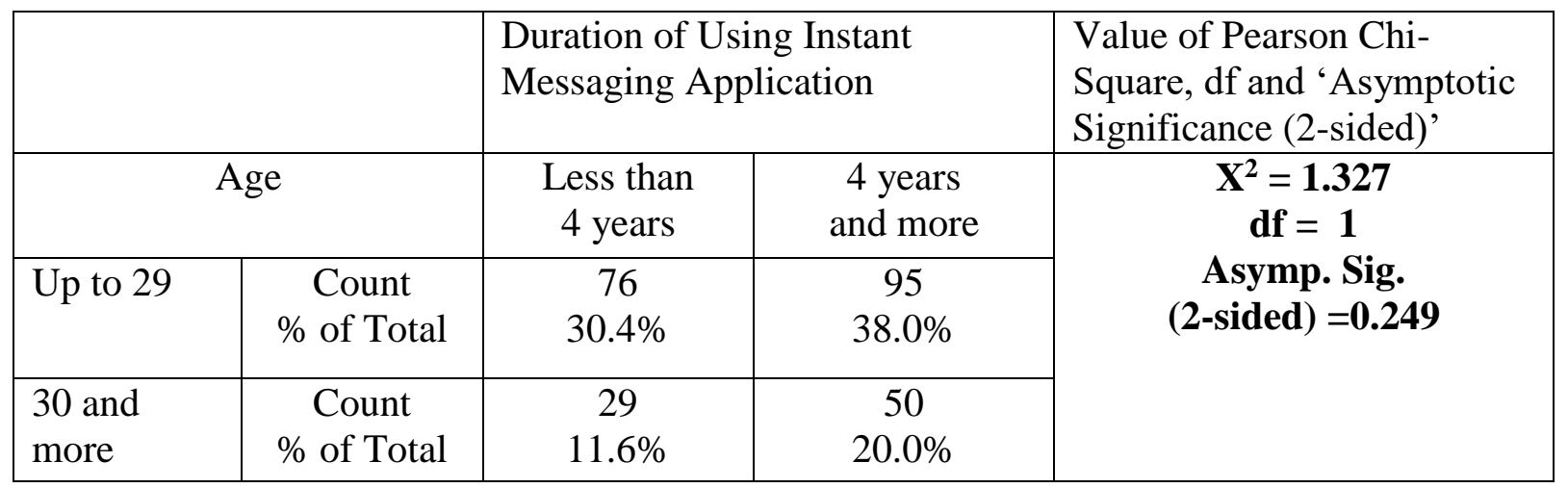




\section{Chi-square test between age and 'frequency of using instant message applications'}

A chi-square test of independence was performed to examine the relation between age and 'frequency of using instant message applications'. The relation between these two variables was not significant, $\mathrm{X} 2(1, \mathrm{~N}=250)=1.108, \mathrm{p}>.05(\mathrm{p}=0.293)$.

The following table (13) shows all the important results of Pearson Chi-square test. The table also shows the frequency distribution of the variables in the different cells along with the value of chi-square, df and 'Asymptotic Significance (2-sided)'.

Table: (13)

Chi-Square Test between Age and 'Frequency of Using Instant Messaging Application'

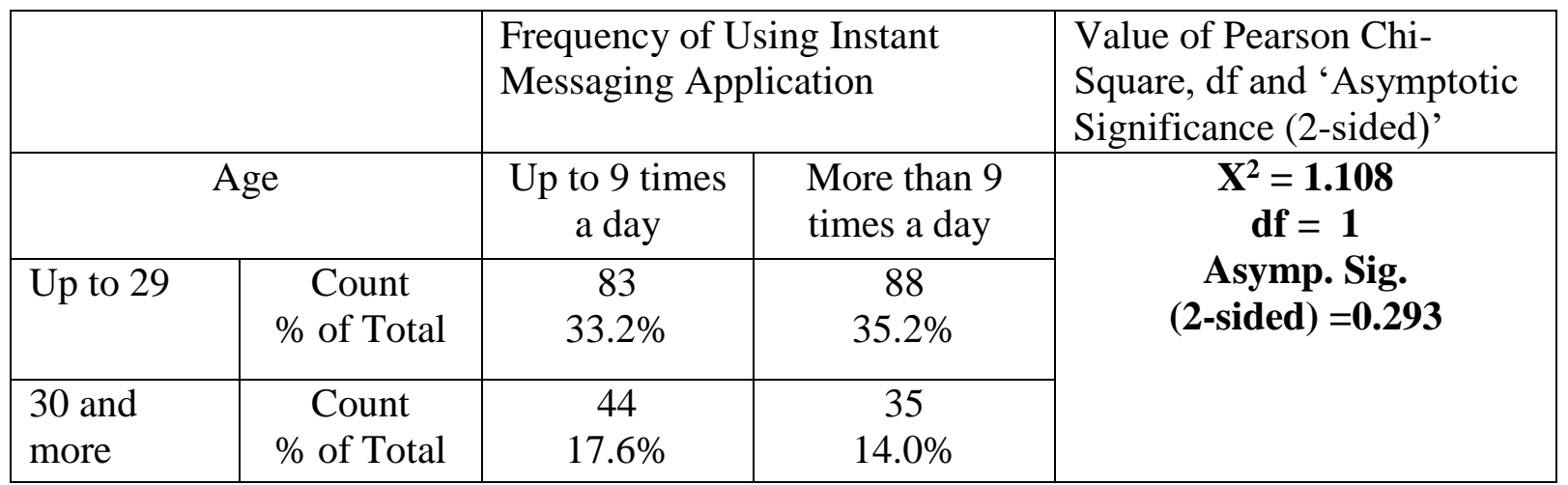

\section{Chi-square test between Education and 'Duration of using instant message applications'}

A chi-square test of independence was performed to examine the relation between Education and 'Duration of using instant message applications'. The relation between these two variables was not significant, $\mathrm{X} 2(1, \mathrm{~N}=250)=0.015, \mathrm{p}>.05(\mathrm{p}=0.902)$. 
The following table (14) shows all the important results of Pearson Chi-square test. The table also shows the frequency distribution of the variables in the different cells along with the value of chi-square, df and 'Asymptotic Significance (2-sided)'.

Table: (14)

Chi-Square Test between Education and 'Duration of Using Instant Messaging Application'

\begin{tabular}{|c|c|c|c|c|}
\hline & & \multicolumn{2}{|c|}{$\begin{array}{l}\text { Duration of Using Instant } \\
\text { Messaging Application }\end{array}$} & $\begin{array}{l}\text { Value of Pearson Chi- } \\
\text { Square, df and 'Asymptotic }\end{array}$ \\
\hline \multicolumn{2}{|c|}{ Education } & Less than & 4 years & $\mathrm{X}^{2}=0.015$ \\
\hline $\begin{array}{l}\text { Up to } \\
\text { Diploma }\end{array}$ & $\begin{array}{c}\text { Count } \\
\% \text { of Total }\end{array}$ & $\begin{array}{c}37 \\
14.8 \%\end{array}$ & $\begin{array}{c}50 \\
20.0 \%\end{array}$ & $\begin{array}{c}\text { Asymp. Sig. } \\
\text { (2-sided) }=0.902\end{array}$ \\
\hline $\begin{array}{l}\text { Bachelor } \\
\text { and more }\end{array}$ & $\begin{array}{c}\text { Count } \\
\% \text { of Total }\end{array}$ & $\begin{array}{c}68 \\
27.2 \%\end{array}$ & $\begin{array}{c}95 \\
38.0 \%\end{array}$ & \\
\hline
\end{tabular}

\section{Chi-square test between Education and 'frequency of using instant message applications'}

A chi-square test of independence was performed to examine the relation between Education and 'frequency of using instant message applications'. The relation between these two variables was not significant, $\mathrm{X} 2(1, \mathrm{~N}=250)=1.242, \mathrm{p}>.05(\mathrm{p}=0.265)$.

The following table (15) shows all the important results of Pearson Chi-square test. The table also shows the frequency distribution of the variables in the different cells along with the value of chi-square, df and 'Asymptotic Significance (2-sided)'. 
Table: (15)

Chi-Square Test between Education and 'Frequency of Using Instant Messaging

Application'

\begin{tabular}{|c|c|c|c|c|}
\hline & & \multicolumn{2}{|c|}{$\begin{array}{l}\text { Frequency of Using Instant } \\
\text { Messaging Application }\end{array}$} & $\begin{array}{l}\text { Value of Pearson Chi- } \\
\text { Square, df and 'Asymptotic }\end{array}$ \\
\hline \multicolumn{2}{|c|}{ Education } & Up to 9 times & More than 9 & \multirow{3}{*}{$\begin{array}{c}\mathrm{X}^{2}=1.242 \\
\mathrm{df}=1 \\
\text { Asymp. Sig. } \\
(2 \text {-sided) }=\mathbf{0 . 2 6 5}\end{array}$} \\
\hline $\begin{array}{l}\text { Up to } \\
\text { Diploma }\end{array}$ & $\begin{array}{c}\text { Count } \\
\% \text { of Total }\end{array}$ & $\begin{array}{c}40 \\
16.0 \%\end{array}$ & $\begin{array}{c}47 \\
18.8 \%\end{array}$ & \\
\hline $\begin{array}{l}\text { Bachelor } \\
\text { and more }\end{array}$ & $\begin{array}{c}\text { Count } \\
\% \text { of Total }\end{array}$ & $\begin{array}{c}87 \\
34.8 \%\end{array}$ & $\begin{array}{c}76 \\
30.4 \%\end{array}$ & \\
\hline
\end{tabular}

\section{CONCLUSION}

This study has focused on the use of IMA in Kuwait as research about the Gulf region is scarce and not as much attentive to researchers as other regions in the world. There's a lack of understanding about the use and adoption of communication technology in general. Specifically, the use and adoption of social media in the Gulf region as it is the main trend and fashion in communication. Thus, this study was aimed at exploring this field in research to understand user's behaviors in this culture and region. The study resulted in interesting findings that are not just applicable in Kuwait but also in all Gulf countries due to the similarity shared in cultures and close borders that have led to interrelations among several families from the same region.

This study has resulted in several findings. Findings indicate all respondents have instant messaging applications and are active users of them. This means that IMA are very much used in Kuwait and among all segments in society. They are used as one of the major methods of communication. Findings are summarized as follows: 
In terms of instant messaging application use results show that the highest number of participants 236 use WhatsApp, the second highest number of participants 151 use Snap Chat, and third highest number of participants 76 use Viber.

In regard to respondent's experiences in IMA results show that the highest number of participants 219 experiences are in using is in text Chat, and the second highest number of participants 176 experience is in Photo Sending, and the third highest number of participants 169 experience is in Group Chat.

Findings also indicate the highest number of contacts that they communicate with using IMA is friends, the second highest is family, and the lowest number of contacts with whom participants communicate with is Businesses.

In regard to the most important features of IMA, participants claim that their ability to interact with groups at the same time is the most important feature to them, while the second highest feature of IMA is that it is free of charge, and the third highest features of IMA is that it is simple to use. Results show differences in males and females in their perception about IMA, where females have greater IMA experiences and perceive more features than males when using IMA.

The results show that the highest number of participants use WhatsApp, the second highest use Snap Chat and third highest use Viber. The results show that the highest number of participants $123(49.2 \%)$ use instant messaging applications more than 10 times a day. The lowest number of participants 14 (5.6\%) use instant messaging applications about 1-2 times in a month.

\section{IMPLICATIONS FOR PRACTICE}


This study has generated vital practical implications. First, this study has added knowledge to the scarce and limited research of information and communication technology specifically the use of instant messaging application in the Gulf region and especially in Kuwait. No previous research has examined the effect of gender, age, and education on the users IMA use in relation to user's contacts, experiences, and perceived features of IMA.

Second, one of the main strategies of the Gulf countries is to foster and fund the initiation of small businesses in the region. Therefore, in relation to practice, as evident in the findings instant messaging applications are important communications sources for users in Kuwait and throughout the Gulf, they are considered one of the major sources communication mediums used by different categories of users. This finding bears important implications for the Gulf countries in general as all Gulf countries acquire similar financial, economic, and cultural environments. Therefore this study bears important practical implications for small business owners and entrepreneurs in general throughout the Gulf countries, since it has been evident that IMA are used intensively by users, business owners should take advantage of such a phenomenon and focus their marketing strategies on IMA in an effective and efficient method, where costs are less and business owners are able to reach huge numbers of users in very fast and simple ways throughout different Gulf countries. This study recommends and highlights the importance of IMA use throughout the Gulf countries for entrepreneurs where cross border small businesses can benefit from IMA adoption rates and acceptance among users as a communication medium that should be used by business owners in different Gulf countries. This is especially important for female related products since results show that females have greater IMA experiences and perceive more features than males when using IMA. 
Users of instant messaging applications should also be aware of the attachments related to such use, and the degree of engagement which in return can be a double-sided edge of technology adoption and can take advantage of such high degree of acceptance and use of IMA.

\section{FUTURE RESEARCH}

In terms of future research, first, researchers should perform similar studies in other Gulf countries to see if there are discrepancies in relation to gender, age, and education in adoption trends in relation to users most important IMA features, contact kinds used, and experiences of using IMA, as users of other Gulf countries might favor the use of IMA in certain categories more than others that will be interesting to compare.

Second, future studies should examine the use of IMA in relation to social media adoption since these two field are the latest trends in communication on a worldwide scope. Interesting factors to explore are disadvantages of using IMA and the degree of engagement of users and the side effects

of it since this study indicates $100 \%$ use by respondents, then it is a logical outcome that engagement is high.

Third, future research should also focus on different categories of users in the same region in relation to their perceived advantages and disadvantages of each communication technology. A limitation of the study is the fact that the survey was limited to university population. Future studies should undergo a more general approach to the same study, which would generate more categories of users and differences in demographics. 


\section{REFERENCES}

Alabbasi, D. 2016. WhatsApp, agency and education: The case of female Saudi teachers.

Charting flexible pathways in open and distance education, 236.

Church, K., \& de Oliveira, R. 2013. What's up with whatsapp?: comparing mobile instant messaging behaviors with traditional SMS. In Proceedings of the 15

Grinter, R. \& Eldridge, M. 2001. y do tngrs luv 2 txt msg?, Proceedings of ECSCW ‘01, Bonn, Germany, 219-238.

Grinter, R. \& Palen, L. 2002. Instant Messaging in Teen Life, Proceedings of CSCW ‘02, New Orleans, LA.

Isaacs, E., Walendowski, A., Whittaker, S., Schiano, D. J., \& Kamm, C. 2002. The character, functions, and styles of instant messaging in the workplace. In Proceedings of the $2002 \mathrm{ACM}$ conference on Computer supported cooperative work (pp. 11-20). ACM.

Maheswari, P. U. 2014. Frequency of using WhatsApp Messenger among College Students in Salem District, TamilNadu.

Mahowald, R. \& Levitt, M. 2000. Finding a Place: Corporate Instant Messaging Market Forecast \& Analysis, 2000-2004, IDC Report.

Nardi, B., Whittaker, S. \& Bradner, E. 2000. Interaction and outeraction: instant messaging in action, Proceedings of CSCW '00. Philadelphia, PA, 79-88.

Radicati Group 2001. Instant Messaging and SMS, Market Trends 2001-2004. Radicati Market Report. 
Rhinelander, T. 2000. Intense users will drive increased IM capabilities, Forrester Technographics Brief.

Whittaker, S., Frohlich, D. \& Daly-Jones, W. 1994. Informal Workplace Communication: What is it Like and How Might We Support It?, Proceedings of CHI '94, Boston, MA, 131-137. 